\title{
STRATEGI PENGELOLAAN USAHA KECIL DI MASA PANDEMI COVID 19 DESA WAAI KABUPATEN MALUKU TENGAH
}

\author{
Novalien Carolina Lewaherilla ${ }^{1}$, Victor Ernest Huwae ${ }^{2}$, Agusthina Risambessy ${ }^{3}$ \\ ${ }^{1,2,3)}$ Jurusan Manajemen, Fakultas Ekonomi, Universitas Pattimura \\ e-mail: novalewaherilla@yahoo.com,vickyhuwae@gmail.com, austhin_r@yahoo.com
}

\begin{abstract}
Abstrak
Pandemi Covid-19 yang melanda dunia telah membawa dampak besar pada perekonomian Indonesia. Penurunan kinerja ekonomi sangat dirasakan oleh pelaku usaha mikro, kecil dan menengah (UMKM). Di saat situasi ekonomi terpuruk akibat Virus Corona, pelaku UMKM harus benar- benar mengetahui keputusan apa yang harus dilakukan. Diperlukan strategi yang tepat demi keberlangsungan hidup UMKM. Kegiatan pengabdian ini bertujuan untuk memberikan pemahaman dan penguatan bagi pelaku UMKM di Desa Waai Kecamatan Salahutu Kabupaten Maluku Tengah tentang pengelolaan usaha secara baik di saat Pandemic Covid-19, dengan mengembangkan strategi pemasaran melalui inovasi dan digital marketing, serta memiliki jiwa entrepreneurship yang tangguh sehingga pada akhirnya usaha kecil dapat bertahan di masa krisis. Adapun metode yang digunakan dalam kegiatan ini adalah Penyuluhan atau Ceramah yang bertujuan meningkatkan pemahaman serta kesadaran para pelaku usaha. Hasil dari kegiatan ini adalah terserapnya pengetahuan dan pembentukan motivasi diri dari pelaku UMKM melalui materi yang dipahami sehingga mitra menemukan strategi pengelolaan usaha yang tepat untuk tetap bertahan dan berkembang di masa pandemic Covid-19.
\end{abstract}

Kata kunci: Strategi, Pengelolaan, Usaha Kecil

\section{Abstract}

The COVID-19 pandemic that has hit the world has had a major impact on the Indonesian economy. The decline in economic performance was felt by micro, small and medium enterprises (MSMEs). When the economic situation is down due to the Corona Virus, MSME actors must really know what decisions to make. The right strategy is needed for the survival of MSMEs. This service activity aims to provide understanding and strengthening for MSME actors in Waai Village, Salahutu District, Central Maluku Regency about good business management during the Covid Pandemic, by developing products through innovation, especially in the field of marketing, and have a strong entrepreneurial spirit, so that in Finally, small businesses can survive in times of crisis. The method used in this activity is Counseling or Lectures which aim to increase understanding and awareness of business actors. The result of this activity is the absorption of knowledge and the formation of self-motivation from MSME actors through material that is understood so that partners find the right business management strategy to survive and thrive during the Covid-19 pandemic.

Keywords: Strategy, Management, Small Business

\section{PENDAHULUAN}

Usaha Mikro, Kecil, dan Menengah (UMKM) merupakan salah satu bidang usaha yang dapat berkembang dan konsisten dalam perekonomian nasional. UMKM menjadi wadah yang baik bagi penciptaan lapangan pekerjaan yang produktif. . Perkermbangan usaha kecil saat ini mengalami kondisi yang cukup memprihantinkan. Kondisi yang terjadi pada saat Wabah Covid-19 membuat sektor ekonomi dan usaha kecil begitu terpuruk. Banyak pelaku usaha mikro, kecil, dan menengah (UMKM) diperhadapkan dengan keadaan resesi ekonomi yang juga menghambat kemajuan usahanya bahkan kedapatan banyak yang gulung tikar. Pendapatan yang diterima menurun akibat berkurangnya pelanggan sejak diberlakukannya PSBB dan physical distancing.

Indonesia didominasi oleh UMKM yang menjadi tulang punggung perekonomian nasional juga terdampak serius bukan hanya pada aspek produksi dan pendapatan mereka saja, namun juga pada 
jumlah tenaga kerja yang harus dikurangi dikarenakan pandemi ini.(Pakpahan,2020). Ketidakpastian pasar membuat permintaan akan barang yang dijual oleh para UMKM menjadi berpengaruh. Memang usaha mikro, kecil dan menengah ini terdampak signifikan, bukan saja di kota-kota besar di Indonesia, tapi juga dirasakan pada masyarakat kecil seperti masyarakat Desa Waai Kecamatan Salahutu Kabupaten Maluku Tengah.

Desa Waai adalah salah satu desa yang terletak di Pulau Ambon, Kecamatan Salahutu, Kabupaten Maluku Tengah. Keberadaan Usaha Mikro Kecil dan Menengah (UMKM) di desa Waai yang terdiri dari beragam usaha baik usaha di bidang perikanan, kuliner, dan dagang merupakan bagian yang turut menopang pekonomian masyarakat. Kondisi yang terjadi adalah terjadi kemunduran pada usaha kecil yang ada di desa Waai, dimana daya beli masyarakat menjadi rendah, sehingga pendapatan yang diterima pelaku usaha kecil juga mengalami penurunan. terutama sejak tahun 2020. Terkait dengan itu juga, akibat himbauan pemerintah tentang protokol kesehatan telah membatasi pergerakan orang dan barang dan sangat berdampak pada terbatasnya operasional UMKM dan berkurangnya konsumen yang berbelanja secara langsung dibandingkan hari biasa. Para pelaku usaha mengalami kewalahan dalam menemukan bagaimana strategi pengeloaan usaha secara baik di masa Pandemic Covid-19 ini, karena mereka sulit untuk bertahan apalagi bersaing di masa yang serba sulit ini. Hasil penelitian dari Narto (2020) menemukan strategi pemasaran pada di tengah pandemi Covid-19 untuk meningkatkan keunggulan bersaing UMKM Kota Gresik hasil penelitian tersebut adalah wabah Covid-19 yang melanda dunia mengakibatkan beberapa sektor industri termasuk Usaha Mikro Kecil Menengah (UMKM) di kota Gresik juga mengalami dampak turunnya tingkat penjualan sehingga keuntungan yang diperoleh hanya berkisar 7\% dalam kurun waktu 1 bulan. Selain itu Darwis Agustriyana (202) menemukan bahwa diperlukan semangat berwirausaha bagi UMKM di Jawa Barat dalam menghadapi masa sulit selama pandemic Covid-19 serta membentuk dan memberikan pengarahan dalam menyusun strategi bertahan dan inovasi yang dapat dilakukan para pelaku UMKM untuk bertahan di tengah kondisi pandemic Covid-19.

Dalam menghadapi tantangan pada masa Pandemic Covid-19 ini maka menumbuhkan dan mengembangkan UMKM supaya tetap survive harus dijalankan.. Keinginan seseorang untuk menumbuhkan mental bertahan dan mengembangkan kreatifitas serta inovasi di masa-masa sulit menjadi kebutuhan mendesak. Kuncinya adalah mau belajar mengenali kelebihan dan kekurangan usaha yang dijalankan terutama dampak yang ditimbulkan Covid-19 ini bagi usaha mereka, dan berusaha mengelola dan mengembangkan jiwa wirausaha serta menciptakan hal-hal yang baru. Dalam upaya meningkatkan perkembangan dan pertumbuhan usaha kecil, maka langkah awal adalah mempelajari karakteristik serta permasalahan yang dihadapi oleh UMKM ( Winardi, 2003). Persoalan dan masalah yang dihadapi oleh kelompok usaha ini adalah bagaimana mengelola usaha secara baik untuk dapat bertahan di masa pandemic Covid-19, terutama manajemen pemasaran dan strategi inovasi . Meskipun penuh dengan keterbatasan, tetapi keinginan dan harapan sederhana dalam diri mereka, membuat mereka gigih untuk memproduksi dan memasarkan produk, untuk menambah pendapatan keluarga, terutama komsumsi rumah tangga dan biaya pendidikan anak. Tujuan dari kegiatan pengabdian ini adalah memberikan pemahaman tentang Strategi Pengelolaan Usaha, terutama manajemen pemasaran melalui inovasi dan digital marketing serta menumbuhkan jiwa entrepreneurship yang tangguh. di masa Pandemic Covid-19.

\section{METODE}

Adapun metode yang digunakan dalam kegiatan ini adalah Penyuluhan atau Ceramah yang bertujuan meningkatkan pemahaman serta kesadaran para pelaku usaha tentang bagaimana mengelola usaha kecil di masa pandemic Covid-19. Kegiatan sosialisasi dimulai dengan mengemukakan situasi yang terjadi pada masa Pandemic Covid-19 serta pengaruhnya pada perkembangan usaha kecil di Indonesia. Selanjutnya diajak berdiskusi dan sharing tentang masalah yang dihadapi oleh pelaku usaha saat ini, dan mengemukakan solusi yang harus dilakukan untuk mengembangkan usaha di masa pandemi Covid-19. Sebelum dilakukan penyuluhan atau sosialisasi didahului dengan studi lapangan dan pendekatan awal dengan kepala desa serta pelaku-pelaku usaha. Selanjutnya Pemberian Materi dan Pelatihan dilakukan dengan tema Strategi Pengelolaan Usaha di Masa Pandemic Covid-19. 


\section{HASIL DAN PEMBAHASAN}

Hasil kegiatan PKM secara garis besar terdiri dari ketercapaian target jumlah peserta, ketercapaian tujuan kegiatan, serta ketercapaian target materi yang telah direncanakan., Kegiatan pengabdian kepada masyarakat dilakukan dengan melibatkan 15 pelaku usaha kecil, dan sebagai Nara Sumber adalah kami sebagai Tenaga Pengajar Fakultas Ekonomi Jurusan Manajemen Universitas Pattimura Ambon.

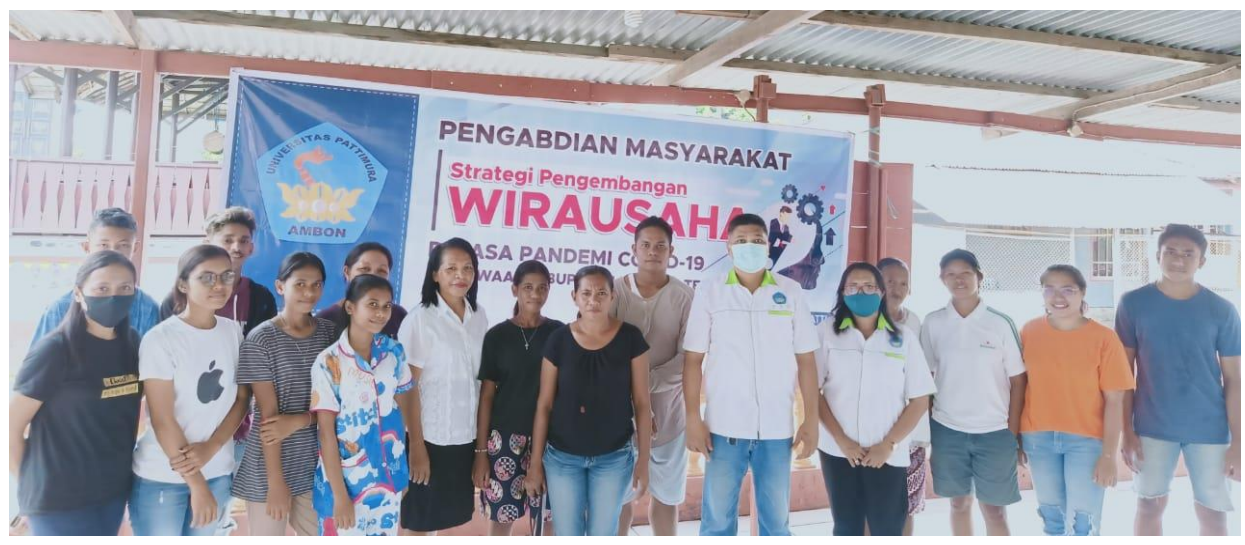

Gambar 1. Foto bersama dengan Perserta kegiatan Pengabdian Masyarakat

Adapun materi pertama yang disampaikan antara lain berupa: Karekteristik utama yang harus dimiliki untuk menjadi wirausaha di masa Krisis. Pada sesi ini mitra diberikan pemahaman bagaimana tipe seorang wirausaha dan apa yang dimiliki supaya bisa menjadi seorang wirausaha dapat bertahan di masa Pandemic Covid 19. Dimana entrepreneur atau wirausaha adalah orang yang berjiwa berani mengambil risiko untuk membuka usaha dalam berbagai kesempatan. Berjiwa berani mengambil risiko artinya bermental mandiri dan berani memulai usaha, tanpa diliputi rasa takut atau cemas sekalipun dalam kondisi tidak pasti. Seorang wirausaha haruslah seorang yang mampu melihat ke depan. Melihat kedepan dan berfikir dengan penuh perhitungan, mencari pilihan dari berbagai alternatif masalah dan pemecahannya. Dalam situasi Pandemi Covid-19 yang penuh ketidakpastian, seorang entrepreneur harus berpikir kritis dan berusaha mencari solusi terbaik untuk dapat mengembangkan usahanya. Ciri-ciri orang yang berjiwa entrepreneur yaitu: mempunyai visi, kreatif, inovatif, mampu melihat peluang, orientasi pada laba dan pertumbuhan, berani menanggung risiko, berjiwa kompetisi, cepat tanggap dan gerak cepat.

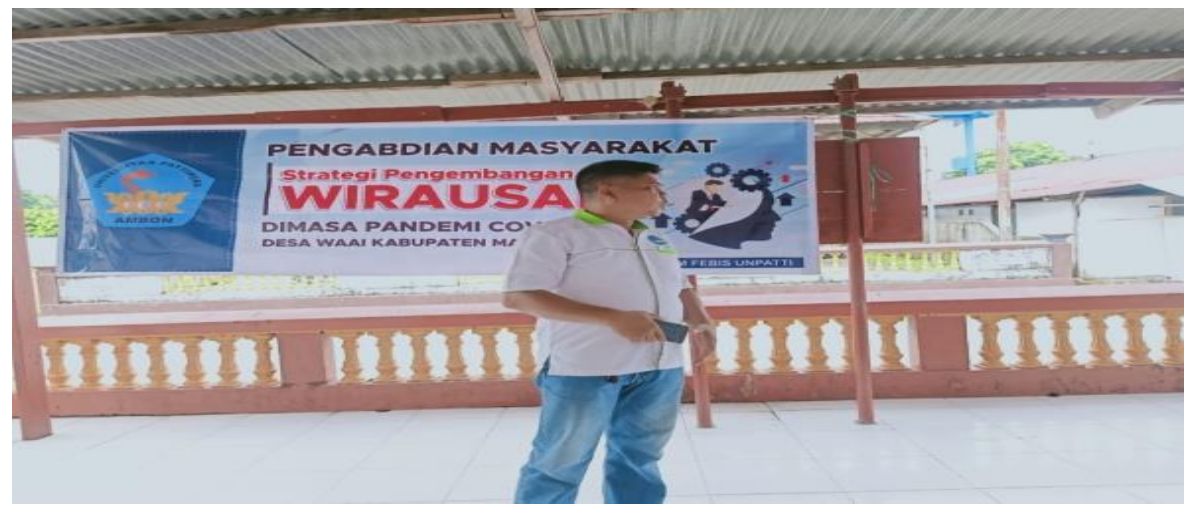

Gambar 2. Narasumber sedang menjelaskan tentang materi pengabdian Masyarakat

Materi yang tidak kalah pentingnya juga adalah strategi pemasaran e-marketing dan inovasi produk sebagai salah satu solusi terbaik dalam menjawab masalah yang terjadi pada usaha kecil selama masa pandemic Covid-19. Menurut Bessant dan Tidd (2011) Inovasi terbagi atas inovasi produk, proses, posisi dan paradigma. Inovasi produk berkaitan dengan produk baru ke pasar. 
Inovasi proses lebih berhubungan dengan diferensiasi produk dan inovasi posisi berhubungan dengan cara baru dalam memperkenalkan produk, sementara inovasi paradigma berkaitan dengan cara pandang dan mental yang dibutuhkan dalam melakukan aktivitas bisnis. Dalam situasi pandemic seperti ini, hal yang paling penting diperhatikan juga adalah finasial dan pasar Dari sisi finansial, pandemi Covid-19 telah berdampak besar bagi UMKM, terutama penurunan pendapatan mereka. Disisi lain, para pelaku usaha membutuhkan sejumlah finansial supaya mereka dapat bertahan hidup.. Itu artinya, inovasi juga memerlukan dukungan finansial

Yang tak kalah pentingnya adalah persaolan digital marketing, sebagai salah satu solusi dalam promosi untuk menambah volume penjualan. Dalam masa pandemic Covid-19. Digital marketing menurut Chakti A.G (2019) adalah upaya yang dilakukan dalam hal pemasaran dengan menggunakan perangkat yang terhubung dengan internet. Dimana dengan digital marketing para pelaku usaha dapat menjangkau konsumen dengan membuka membuka toko online. Ini merupakan sistem penjualan, pembelian dan memasarkan produk dengan memanfaatkan elektronik (Kotler, Philip dan Amstrong, 2012). Dalam Penelitian (Hardilawati, 2019) menyimpulkan bahwa e-commerce memiliki pengaruh positif dan signifikan terhadap peningkatan kinerja pemasaran dan pendapatan UMKM sebagai contoh beberapa akses dalam digital marketing yaitu website, blog, media sosial (instagram, whatsapp, Facebook). Digital marketing adalah salah satu kegiatan promosi dan pencarian pasar melalui media digital secara online dengan memanfaatkan berbagai sarana seperti halnya jejaring sosial (Tabroni dan Mamay Komarudin,2021).

Dengan adanya materi-materi yang disampaikan, diharapkan dapat terjadi transfer knowledge kepada pelaku usaha kecil tentang keadaan pandemic Covid-19 saat ini serta pengaruhnya pada usaha kecil. Selain itu terjadi diskusi dan sharing tentang masalah yang dihadapi selama menjalankan usahanya khususnya pada saat terjadinya pandemic Covid-19 serta membahas bagaimana langkah yang harus dilakukan untuk bertahan di masa pandemic ini. Materi yang disampaikan kepada peserta pelatihan telah sesuai dan mudah dipahami, sehingga mitra sangat antusias ketika diadakan sesi diskusi dan bersama-sama mencari strategi pengelolaan usaha yang tepat lewat inovasi, digital marketing dan penguatan jiwa entrepreneurship di masa pandemic Covid-19.

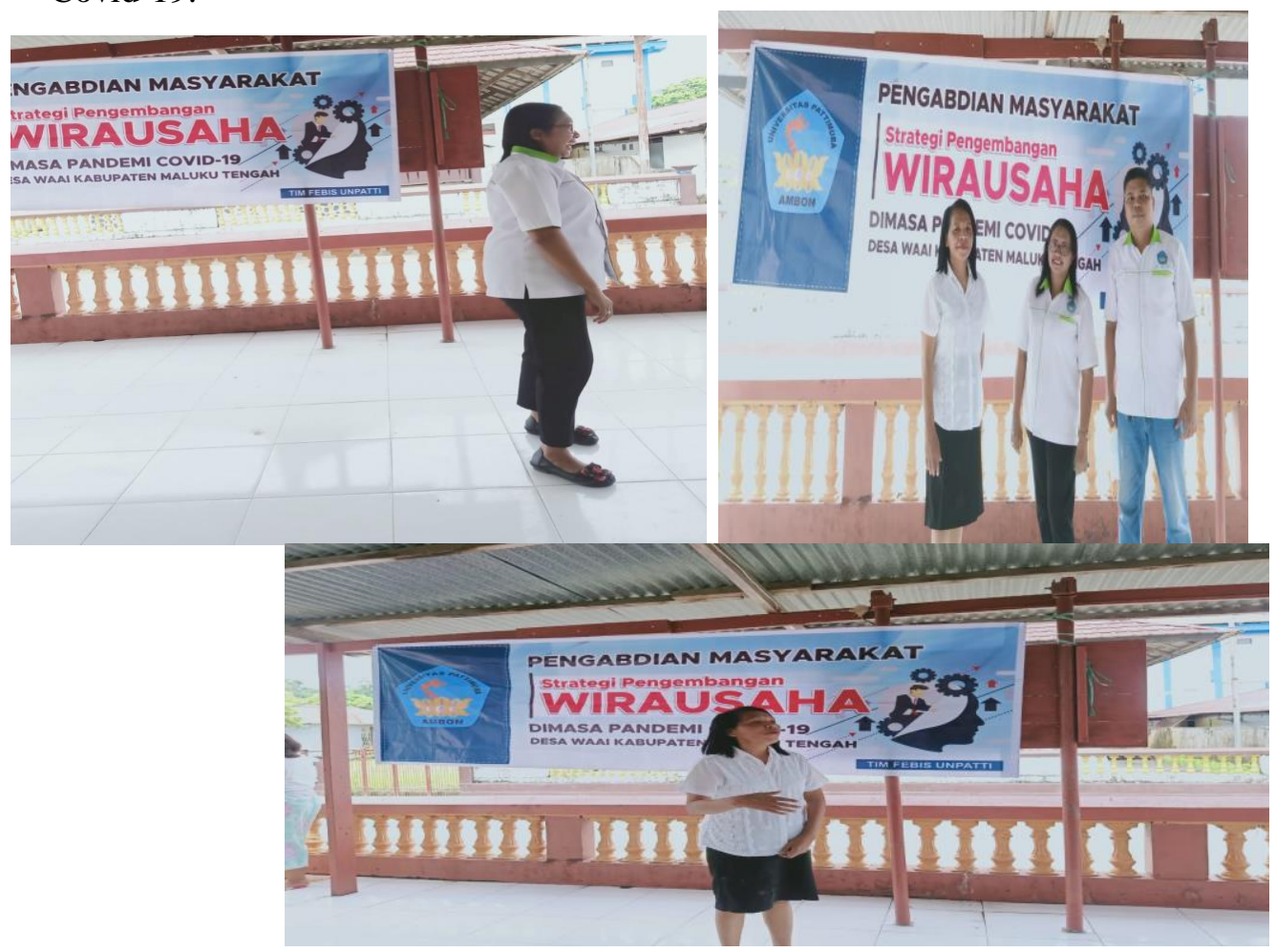

Gambar 3. Narasumber sedang menjelaskan terkait materi pengabdian masyarakat kepada peserta 


\section{SIMPULAN}

Beberapa hal yang dapat disimpulkan dari hasil kegiatan Pengabdian Kepada Masyarakat adalah bahwa kondisi Pandemic Covid-19 berdampak pada semua sektor diantaranya usaha kecil di Desa Waai Kecamatan Salahutu Kabupaten Maluku Tengah. Pentingnya pemahaman tentang pentingnya strategi pengelolaan usaha baik dari sisi marketing dan pengembangan jiwa entrepreneurship di masa Pandemic Covid-19 menjadi sebuah pilihan strategis bagi peningkatan usaha kecil, Dengan demikian bagi usaha kecil sesungguhnya yang dibutuhkan adalah perubahan pola pikir untuk lebih bangkit dari keterpurukan agar bisa bertahan dimasa-masa yang sulit melalui pengeloaan usaha yang lebih baik serta inovasi yang berkelanjutan.

\section{SARAN}

Bagi pengembangan UMKM selanjutnya khusus di desa- desa dalam wilayah Maluku, maka saran kami selanjutnya adalah kegiatan pengabdian harus lebih berfokus pada pengembangan dan perluasan usaha serta pemberdayaan usaha kecil sesuai potensi dan kearifan lokal.

\section{UCAPAN TERIMA KASIH}

Penulis mengucapkan terima kasih kepada Pemerintah Desa Waai Kecamatan Salahutu Kabupaten Maluku tengah yang telah mendukung terselenggranya kegiatan pengabdian ini serta pihak Fakultas Ekonomi Universitas Pattimura yang sudah memberikan kepercayaan bagi kami untuk pelaksanaan kegiatan ini.

\section{DAFTAR PUSTAKA}

Bessant, John., dan Joe Tidd. (2011). Innovation and Entrepreneurship. Second Edition. John Wiley \& Sons, Ltd

Chakti, A. G. (2019). The Book Of Digital Marketing. Makasar: Celebes Media Perkasa. Pamungkas, B. A., dan Siti Z. (2016). Pengaruh Promosi Di Media Sosial Dan Word Of Mouth Terhadap Keputusan Pembelian (Studi Kasus Pada Kedai Bontacos Jombang). Jurnal Komunikasi, x(2), 145.

Darwis Agustriyana et al. ( 2021)Bertahan Usaha pada UMKMdi tengah Pandemic Covid 19, Jurnal Pengabdian Dharma Laksna Mengabdi Untik Negeri . hal 93-100

Hardilawati, W. L.(2019). The Role of Innovation and E-Commerce in Small Business.373,83-8

Kotler, Philip dan Amstrong, G. (2012). Principles of Marketing (15th ed.). Pearson Education Limited.

Narto, G. B. (2020). Penguatan Strategi Pemasaran Pudak Di Tengah Pandemi Covid-19 Untuk Meningkatkan Keunggulan Bersaing Usaha Mikro Kecil Menengah Kota Gresik . Jurnal INTECH Teknik Industri ,( 48-54)

Tabroni dan Mamay (2021) Jurnal Riset Entrepreneurship e-ISSN: 2621-153X http://journal.umg.ac.id/index.php/jre JRE 4 (1) 2021, (49-57 )doi:10.30587/jre.v4i1.2217

Pakpahan, A.K.(2020).COVID-19 dan Implikasi Bagi Usaha Mikro, Kecil, dan Menengah.

Winardi J (2003). Entrepreneur dan Entrepreneuship. Penerbit Kencana Prenada 